University of Nebraska - Lincoln

DigitalCommons@University of Nebraska - Lincoln

Faculty Publications from the Harold W. Manter Laboratory of Parasitology

2009

\title{
Caecincola longiscens n. sp. (Digenea: Cryptogonimidae) from the White Crappie, Pomoxis annularis, in Mississippi, U.S.A.
}

\author{
Stephen S. Curran \\ Gulf Coast Research Laboratory, stephen.curran@usm.edu \\ Robin M. Overstreet \\ Gulf Coast Research Laboratory, robin.overstreet@usm.edu
}

Follow this and additional works at: https://digitalcommons.unl.edu/parasitologyfacpubs

Part of the Parasitology Commons

Curran, Stephen S. and Overstreet, Robin M., "Caecincola longiscens n. sp. (Digenea: Cryptogonimidae) from the White Crappie, Pomoxis annularis, in Mississippi, U.S.A." (2009). Faculty Publications from the Harold W. Manter Laboratory of Parasitology. 435.

https://digitalcommons.unl.edu/parasitologyfacpubs/435

This Article is brought to you for free and open access by the Parasitology, Harold W. Manter Laboratory of at DigitalCommons@University of Nebraska - Lincoln. It has been accepted for inclusion in Faculty Publications from the Harold W. Manter Laboratory of Parasitology by an authorized administrator of DigitalCommons@University of Nebraska - Lincoln. 


\title{
Caecincola longiscens $\mathbf{n}$. sp. (Digenea: Cryptogonimidae) from the White Crappie, Pomoxis annularis, in Mississippi, U.S.A.
}

\author{
Stephen S. Curran ${ }^{1}$ and Robin M. OverstreEt \\ Department of Coastal Sciences, The University of Southern Mississippi, 703 East Beach Drive, Ocean Springs, \\ Mississippi, 39564 U.S.A. (email: stephen.curran@usm.edu; robin.overstreet@usm.edu)
}

ABSTRACT: A new cryptogonimid trematode is described from the white crappie, Pomoxis annularis Rafinesque, 1818, collected from Lake Chotard, an oxbow lake directly connected to the Mississippi River in Issaquena County, and from a small ephemeral oxbow periodically connected with the Pascagoula River in Jackson County, both in Mississippi, U.S.A. Caecincola longiscens $\mathrm{n}$. $\mathrm{sp}$. is characterized by having an elongated body with a length to width ratio of 5.5-7.5:1, tandem testes, an elongated tubular seminal vesicle, and vitelline follicles confined to the hindbody.

KEY WORDS: Digenea, Cryptogonimidae, Caecincola longiscens n. sp., white crappie, Pomoxis annularis, Lake Chotard, Pascagoula River, Mississippi, U.S.A.

We encountered specimens of an unknown digenean species from the white crappie, Pomoxis annularis Rafinesque, 1818, while surveying fish for parasites at 2 inland locations in Mississippi, U.S.A. The species belongs in Cryptogonimidae Ward, 1917 because it has scale-like body spines, eyespots, an elongated Y-shaped excretory vesicle with the main stem branching in the testicular zone, and arms extending anteriorly to the pharynx level (see Price [1940]), and the genital pore and ventral sucker are contained within a ventrogenital sac (Manter, 1926; Cable and Hunninen, 1942; Pearson, 2002; Miller and Cribb, 2008). Because the species lacks a gonotyl or circumoral spines associated with the oral sucker, the oral sucker is broad and funnelshaped, the ovary is trilobed, and the ceca terminate in the testicular zone, it conforms reasonably to the diagnoses for Caecincola Marshall and Gilbert, 1905 provided by Gibson (1996) and Miller and Cribb (2008). The species is described as the fourth species in the genus from a centrarchid.

\section{MATERIALS AND METHODS}

Specimens of $P$. annularis were collected from 2 locations in Mississippi, U.S.A. Four fish were caught from Lake Chotard, Issaquena County, Mississippi, U.S.A., on 29 January 2001, and an additional fish from the same location was caught on 20 March 2002. Eighteen fish were caught from a small oxbow periodically contiguous with the Pascagoula River, Jackson County, Mississippi, U.S.A., on 18 June 2007. Fish were dissected while freshly dead, and digeneans were collected and washed in $0.75 \%$ saline solution and killed with hot water. Digeneans were then placed in 5\% neutral buffered formalin solution and later

\footnotetext{
${ }^{1}$ Corresponding author.
}

stained using Van Cleave's hematoxylin. The stained worms were partially dehydrated in a graded ethanol series, buffered by adding 3 drops of saturated lithium carbonate in $80 \%$ ethanol and 2 drops of butylamine in $80 \%$ ethanol, and then fully dehydrated in absolute ethanol. Dehydrated worms were cleared in clove oil and mounted in Canada balsam. Drawings were made with the aid of a Wild drawing tube. Measurements are presented in micrometers as mean values followed by range values in parentheses.

Specimens of Caecincola latostoma Greer and Corkum, 1979 were collected from the largemouth bass, Micropterus salmoides (Lacepède, 1802), from Reelfoot Lake, Obion County, Tennessee, U.S.A. $\left(36^{\circ} 23^{\prime} 03^{\prime \prime} \mathrm{N}, 89^{\circ} 21^{\prime} 54^{\prime \prime} \mathrm{W}\right)$ on 18 October 2003. These were prepared using the same techniques and used for comparison with the new species. Four voucher specimens of $C$. latostoma were deposited at the United States National Parasite Collection (USNPC), Beltsville, Maryland, U.S.A (USNPC No. 100836).

\section{Caecincola longiscens n. sp. (Figs. 1-4)}

\section{Description}

Based on 8 specimens. Body elongated, 1,476 (1,347-1,650) long, 265 (184-318) wide, covered by scale-like spines; ratio of body length to width 5.5-7.5:1. Oral sucker terminal, funnel-shaped in well fixed specimens; cup-shaped in poorly-fixed specimens or those rolled while applying coverslip; 179 (117-210) long, 178 (148-218) wide. Pharynx 50 (35-63) long, 49 (35-57) wide. Eyespot remnants dispersed in pharyngeal region. Prepharynx about as long as or slightly longer than pharynx. Esophagus about 1.5-2.5 times pharynx length. Ventral sucker 49 (43-60) long, 56 (48-64) wide, recessed in ventrogenital sac. Gonotyl lacking. Forebody 368 (318-396) long, representing 23-28\% of body length. Intestine bifurcating in forebody; ceca thick-walled, terminating blindly in middle third of hindbody. 


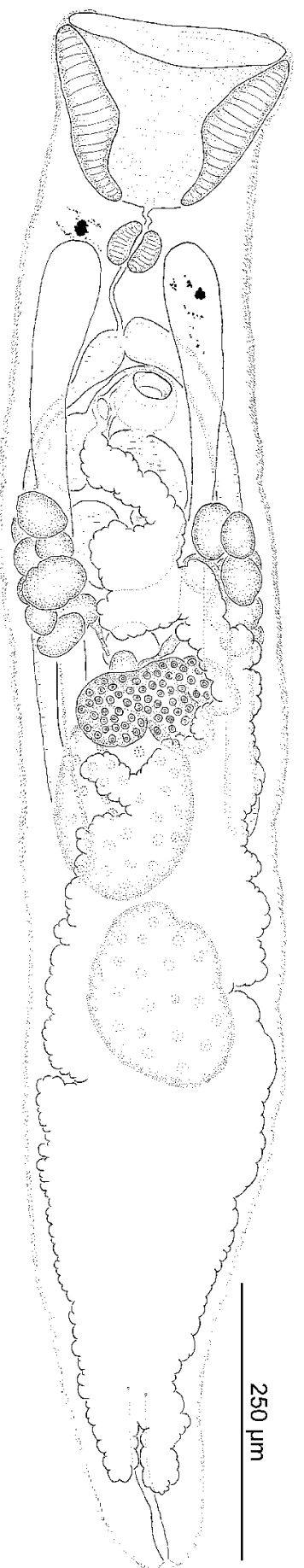

Figure 1. Ventral view of holotype of Caecincola longiscens n. sp. from Lake Chotard, Mississippi, U.S.A.

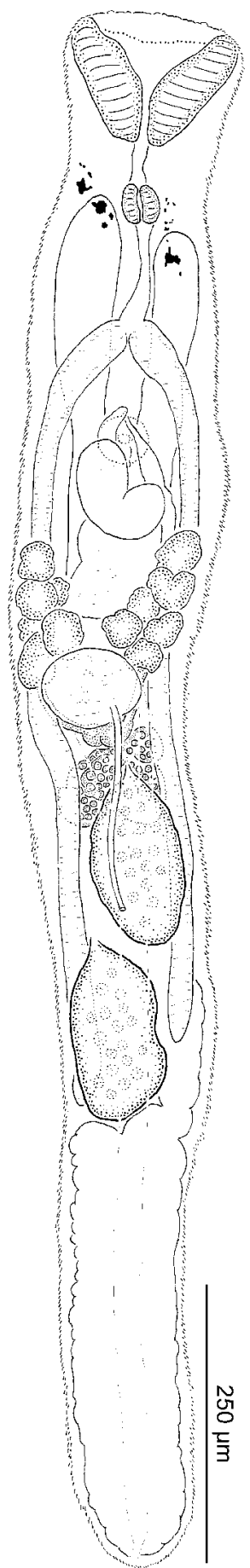

Figure 2. Dorsal view of paratype of Caecincola longiscens n. sp. from the Pascagoula River, Mississippi, U.S.A. 


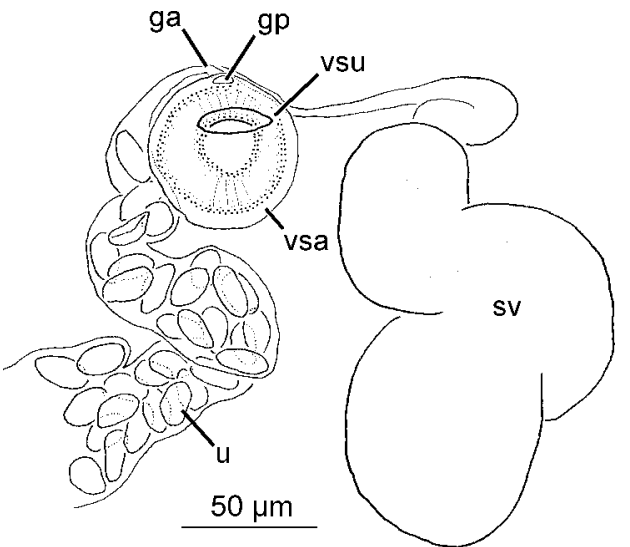

Figure 3. Terminal genitalia of Caecincola longiscens n. sp., ventral view, (ga, genital atrium; gp, genital pore; sv, seminal vesicle; u, uterus; vsa, ventrogenital sac; vsu, ventral sucker)

Postcecal space 533 (413-730) long, representing $28-44 \%$ of body length.

Testes tandem, entire; anterior testis 197 (153-233) long, 133 (82-167) wide; posterior testis 229 (150290) long, 157 (74-240) wide. Posttesticular space 382 (313-427) long, representing 22-30\% of body length. Cirrus sac lacking. Seminal vesicle elongated, looping, longer than body width, 54-114 wide at widest portion, opening into tubular genital atrium; genital atrium 40-60 long. Pars prostatica lacking.

Ovary trilobed, 105 (88-133) long, 158 (113-224) wide, pretesticular, medial. Seminal receptacle canalicular; proximal portion swollen, 64 (59-68) long, 88 (82-94) wide, lying dorsal and anterior to ovary; distal portion narrowing, forming an elongated Laurer's canal; Laurer's canal extending posteriorly and opening on dorsal surface at level of anterior testis, distal-most portion surrounded by glandular cells. Vitellarium consisting of 2 lateral groups of subspherical follicles surrounding ceca in hindbody; groups confined to preovarian region of hindbody. Both groups communicating with common vitelline reservoir through transverse vitelline ducts; vitelline reservoir immediately preovarian, lying between ovary and seminal receptacle. Uterus extending posteriorly from ovarian complex, occupying most of ventral portion of hindbody, filling most of posttesticular region, then extending anteriorly and ventrally to genital atrium, distal portion not muscular but lying ventral to seminal vesicle, almost entirely filled with eggs; eggs operculated, with distal-most ones darkly tanned, 23.5 (20-26) long, 10.5 (9-11) wide.

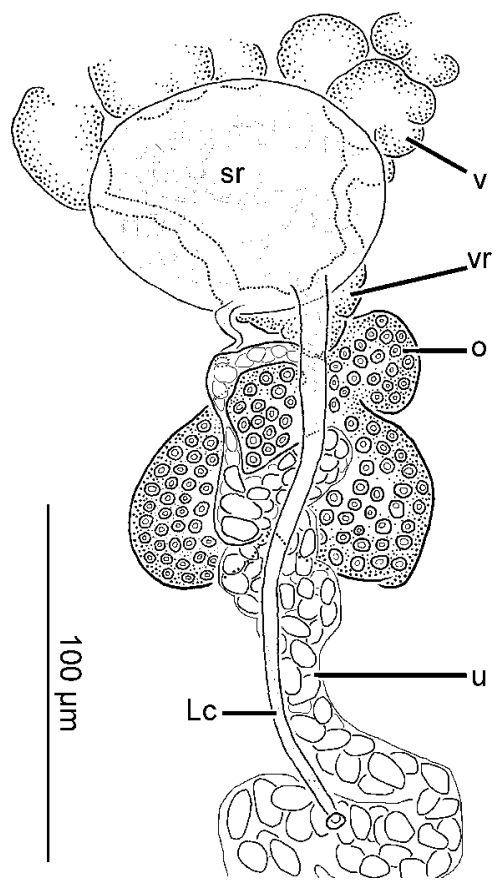

Figure 4. Ovarian complex from paratype of Caecincola longiscens n. sp., dorsal view, (Lc, Laurer's canal; o, ovary; sr, canalicular seminal receptacle; u, uterus; v, vitellaria; vr, vitelline reservoir).

Excretory vesicle Y-shaped; main stem bifurcating at midtesticular level; arms extending dorsal relative to ovary then extending ventral relative to vitelline follicles before continuing anteriorly and ventrally in body, extending to pharynx level; pore terminal.

\section{Taxonomic summary}

Type host: White crappie, Pomoxis annularis Rafinesque, 1818 (Perciformes: Centrarchidae).

Type locality: Lake Chotard, Issaquena County, Mississippi, U.S.A. $\left(32^{\circ} 35^{\prime} 25^{\prime \prime} \mathrm{N}, 91^{\circ} 01^{\prime} 24^{\prime \prime} \mathrm{W}\right)$; other locality at Pascagoula River, Jackson County, Mississippi, U.S.A. $\left(30^{\circ} 36^{\prime} 41^{\prime \prime} \mathrm{N}, 8^{\circ} 38^{\prime} 18^{\prime \prime} \mathrm{W}\right)$.

Sites: Pyloric ceca and intestine.

Specimens deposited: Caecincola longiscens (Holotype) USNPC No. 100837; (2 paratypes) USNPC Nos. 100838-100839.

Specimens examined: Cryptogonimus spinovum (Holotype) USNPC 74808; (2 paratypes) USNPC No. 74809; Caecincola latostoma (Holotype) USNPC No. 74810; (2 paratypes) USNPC No. 74811. 
Etymology: The Latin adjectival present participle longiscens means elongating and refers to the elongating body of the species.

\section{Remarks}

Caecincola longiscens n. sp. shares features common to both Cryptogonimus Osborn, 1903 and Caecincola. Gibson (1996) considered the presence of a gonotyl in Cryptogonimus the only feature useful for separating the 2 genera. As Caecincola is distinguished by the absence of a trait, Gibson (1996) implied that the 2 genera may be synonymous, and we agree. In their recent key to the genera of cryptogonimids, Miller and Cribb (2008) retained Cryptogonimus and Caecincola as distinct genera pending molecular study of the problem. Miller and Cribb (2008) presented diagnoses for Caecincola and Cryptogonimus, and according to these the genera differ in 6 main ways: 1) species in Caecincola are less elongated, having a body length to width ratio of 2-3:1, whereas species in Cryptogonimus have a body length to width ratio of $3-5: 1 ; 2$ ) the oral sucker is wider than long in species of Caecincola but longer than wide in species of Cryptogonimus; 3 ) the ceca may terminate in the anterior hindbody in species of Caecincola and never extend beyond the testes, whereas the ceca terminate more variably in Cryptogonimus, ranging from near the level of the ventral sucker to the posterior extremity depending on the species; 4) the seminal vesicle is bipartite in species of Caecincola and tubular in species of Cryptogonimus; 5) a gonotyl is lacking in species of Caecincola and present in species of Cryptogonimus; 6) vitelline follicles are mainly in the forebody but may extend to the posterior margin of the ventral sucker in species of Caecincola, and they extend from about the middle of the forebody to the level of the gonads in species of Cryptogonimus. We investigated these 6 features in specimens of $C$. longiscens and found that the new species conforms to Cryptogonimus for some features and Caecincola for others. Caecincola longiscens $\mathrm{n}$. sp. has a body length to width ratio (5.5-7.5:1) that exceeds that for both Cryptogonimus and Caecincola. The oral sucker is wider than long, consistent with the diagnosis for Caecincola. The ceca terminate at the testicular level or approximately in the middle of the hindbody, consistent with the diagnosis for Caecincola, but similar to the arrangement found in Cryptogonimus chili Osborn, 1903. The seminal vesicle is elongated, not bipartite, and consistent with the diagnosis for Cryptogonimus. A gonotyl is lacking, consistent with the diagnosis for
Caecincola. Finally, the vitelline follicles are preovarian and confined to the hindbody, an arrangement that is distinct among species of Caecincola or Cryptogonimus. We chose to place $C$. longiscens $\mathrm{n}$. $\mathrm{sp}$. in Caecincola because it lacks a gonotyl, has a distinctly trilobed ovary, and has a funnel-shaped oral sucker that is wider than long. Clearly, the diagnoses for Caecincola and Cryptogonimus include ambiguous features. Placement of the new species in Caecincola should be evaluated using molecular techniques.

Before the present study, 3 species of Caecincola were known. Caecincola longiscens n. sp. is most easily distinguished from its 3 congeners by body shape and size, configuration of the testes, position of the vitellaria, and egg shape. It has a much larger, more elongated body than any of its congeners, measuring $1,347-1,650 \mu \mathrm{m}$ long by $184-318 \mu \mathrm{m}$ wide compared with $260-560 \mu \mathrm{m}$ long by $107-230 \mu \mathrm{m}$ wide for Caecincola parvulus Marshall and Gilbert, 1905, 310-610 $\mu \mathrm{m}$ long by 150-200 $\mu \mathrm{m}$ wide for Caecincola wakullata Premvati, 1967, and 516-856 $\mu \mathrm{m}$ long by 200-336 $\mu \mathrm{m}$ wide for C. latostoma (see Marshall and Gilbert [1905]; Van Cleave and Mueller [1934]; Lundahl, [1941]; Premvati [1967]; Greer and Corkum [1979]). Six specimens of C. latostoma from our collection measured $809-888 \mu \mathrm{m}$ long by 247-360 $\mu \mathrm{m}$ wide and had a much smaller body length to width ratio (2.4-3.5:1) compared with the new species (5.5-7.5:1). The elongated, relatively narrow body of $C$. longiscens confines the testes to a tandem arrangement. In contrast, the 3 congeners have a relatively less narrow hindbody, and all have oblique testes. Caecincola longiscens differs most notably from its congeners by having the vitelline follicles confined wholly to the hindbody rather than having most of the follicles contained within the forebody as in $C$. parvulus and C. latostoma, or wholly distributed in the forebody as in $C$. wakullata. Eggs of C. longiscens, C. latostoma, and C. wakullata lack the spinous process on the abopercular end that is present in eggs of $C$. parvulus.

Species in Caecincola parasitize centrarchid fishes in North America. Caecincola parvulus was described from $M$. salmoides taken from various small lakes near Madison, Wisconsin, U.S.A. (Marshall and Gilbert, 1905). That species also has been reported from the smallmouth bass, Micropterus dolomieu Lacepède, 1802, from Lake Pepin in Wisconsin, U.S.A. (see Pearse [1924]) and the rock bass, Ambloplites rupestris (Rafinesque, 1817), from Lake Michigan off Wisconsin, U.S.A. (see Pearse [1924]); however, Lundahl (1941) considered A. rupestris a facultative host. Van Cleave and Mueller (1934) 
reported the species from $M$. salmoides in Oneida Lake (New York, U.S.A.) but found it absent in $M$. dolomieu and A. rupestris from the same lake. Lundahl (1941) reported C. parvulus from $M$. salmoides from the vicinity of Ann Arbor, Michigan, U.S.A., and from M. dolomieu from Douglas Lake in Michigan, U.S.A. Olson et al. (2003) reported M. parvulus from M. salmoides from the Pascagoula River, Mississippi, U.S.A., and we have since collected $C$. latostoma, but not $C$. parvulus, from $M$. salmoides at that location. Caecincola latostoma was described from M. salmoides and the spotted bass, Micropterus punctulatus (Rafinesque, 1819), from the False River in Pointe Coupee Parish, Louisiana, U.S.A. (Greer and Corkum, 1979). Greer and Corkum (1980) later reported C. latostoma from $M$. salmoides from Beaver Pond Branch in Livingston Parish, Louisiana, U.S.A. We collected C. latostoma from a single specimen of $M$. salmoides from Reelfoot Lake in Tennessee, U.S.A., in the present study. The third species, C. wakullata, was described from M. salmoides from the Wakulla River in Florida, U.S.A. (Premvati, 1967).

\section{ACKNOWLEDGMENTS}

We especially thank Jessica H. Parker (The University of Southern Mississippi), who assisted with fish collections and specimen preparation in the study. We also thank Scott D. Snyder (University Nebraska at Omaha), Michael A. Barger (Peru State College), Vasyl V. Tkach (University of North Dakota), and Jody Peterson and Eric E. Pulis (both from The University of Southern Mississippi) for their assistance with fish collections. We are grateful for the use of facilities at the University of Tennessee-Martin's Reelfoot Lake Research and Teaching Station in Samburg, Tennessee, U.S.A. We appreciate the ideas and insight contributed by William F. Font (Southeastern Louisiana University), and we thank Terry L. Miller (presently at Virginia Institute of Marine Science) and Thomas $\mathrm{H}$. Cribb (both from The University of Queensland) for kindly providing us with a copy of their unpublished chapter on Cryptogonimidae. Patricia A. Pilitt provided bench space and specimens for examination to SSC at the USNPC in Beltsville, Maryland, U.S.A. This material is based upon work supported by the National Science Foundation under grant nos. 0529684 and 0608603.

\section{LITERATURE CITED}

Cable, R. M., and A. V. Hunninen. 1942. Studies on the life history of Siphodera vinaledwardsii (Linton) (Trematoda: Cryptogonimidae). Journal of Parasitology 28:407-422.

Gibson, D. I. 1996. Trematoda. Pages 1-373 in L. Margolis and Z. Kabata, eds. Guide to the Parasites of Fishes of Canada, Part IV. Canadian Special Publication of Fisheries and Aquatic Sciences 124, Ottawa, Canada.

Greer, G. J., and K. C. Corkum. 1979. Life cycle studies of three digenetic trematodes, including descriptions of two new species (Digenea: Cryptogonimidae). Proceedings of the Helminthological Society of Washington 46:188-200.

Greer, G. J., and K. C. Corkum. 1980. Notes on the biology of three trematodes (Digenea: Cryptogonimidae). Proceedings of the Helminthological Society of Washington 47:47-51.

Lundahl, W. S. 1941. Life history of Caecincola parvulus Marshall and Gilbert (Cryptogonimidae, Trematoda) and the development of its excretory system. Transactions of the American Microscopical Society 60: 461-484.

Manter, H. W. 1926. Some North American fish trematodes. Illinois Biological Monographs 10:1-138.

Marshall, W. S., and N. C. Gilbert. 1905. Three new trematodes found principally in black bass. Zoologischen Jahrbuchern 22:476-488.

Miller, T. L., and T. H. Cribb. 2008. Family Cryptogonimidae Ward, 1917. Pages 51-112. in Keys to the Trematoda, Volume 3. R. A. Bray, D. I. Gibson, and A. Jones, eds. CAB International and Natural History Museum, Wallingford and London, UK.

Olson, P. D., T. H. Cribb, V. V. Tkach, R. A. Bray, and D. T. J. Littlewood. 2003. Phylogeny and classification of the Digenea (Platyhelminthes: Trematoda). International Journal for Parasitology 33:733-755.

Pearse, A. S. 1924. The parasites of lake fishes. Transactions of the Wisconsin Academy of Sciences, Arts, and Letters 21:161-194.

Pearson, J. C. 2002. Protoheterophyes spuriocirrus gen. et sp. nov. (Trematoda, Heterophyidae) described and the nature of the gonotyl in heterophyids explicated. Acta Parasitologica 47:205-207.

Premvati, G. 1967. Multigonotylus micropteri gen. et sp. n. and Caecincola wakullata sp. n. (Digenea: Cryptogonimidae) from freshwater bass, Micropterus salmoides. Journal of Parasitology 53:743-746.

Price, E. W. 1940. A review of the trematode superfamily Opisthorchioidea. Proceedings of the Helminthological Society of Washington 7:1-13.

Van Cleave, H. J., and J. F. Mueller. 1934. Parasites of Oneida Lake fishes Part III. A biological and ecological survey of the worm parasites. Roosevelt Wild Life Annals 3:155-373. 